\title{
Effects of Paternal Leadership on Organisational Cynism: Comparing the Public and Private Hospitals in Fath Health Service Region
}

\author{
Esendal GÜLEÇ ${ }^{1}$, Kadriye SÖNMEZ ${ }^{2}$, Suat PEKER ${ }^{3}$ İbrahim Halil CANKUL $^{4}$
}

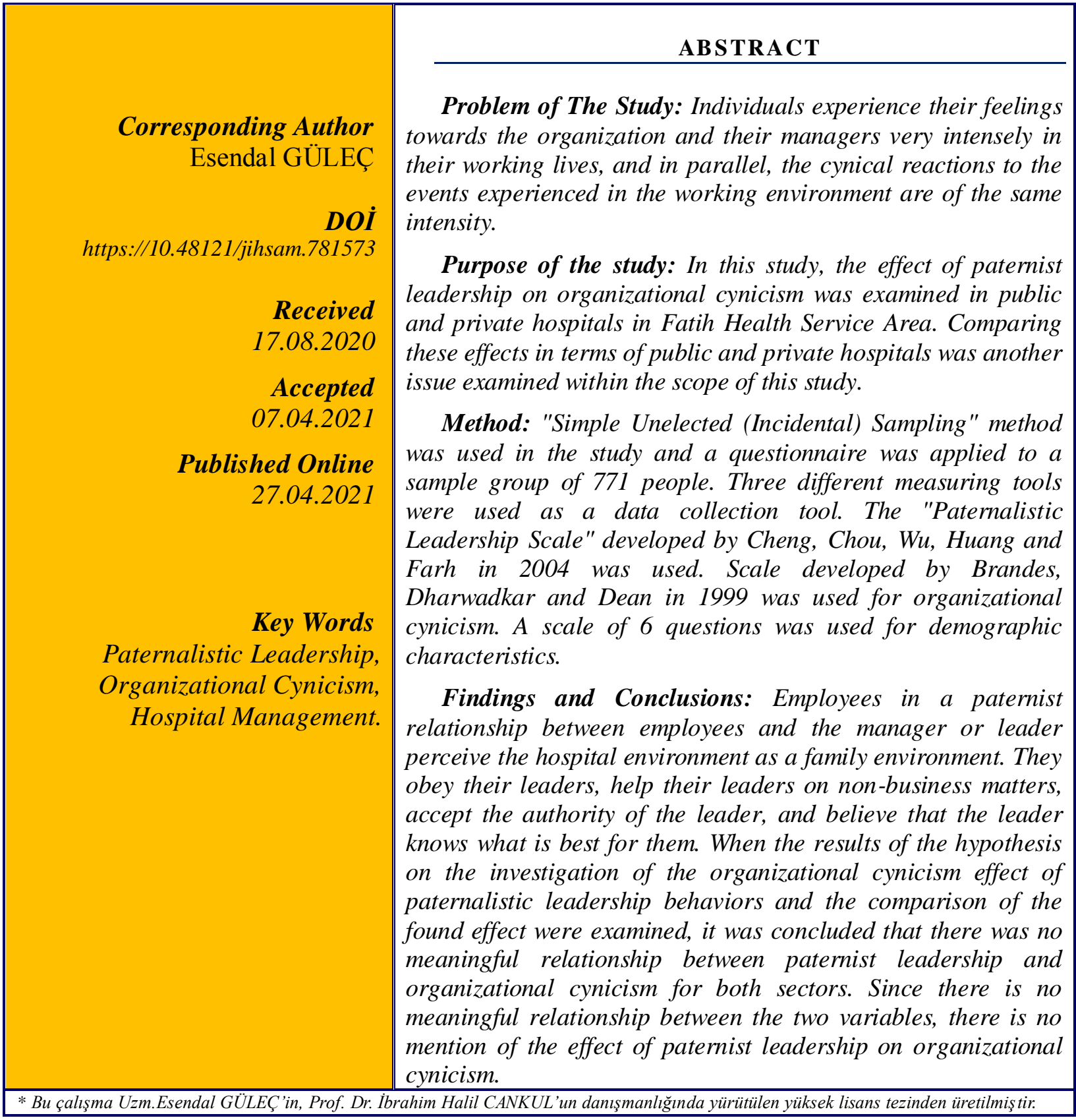

1 Health Institutions Management Program PhD Student, T.R. Uskudar University, Istanbul. gulecesendal@gmail.com, https://orcid.org/0000-0003-0753-3048

2 Medical Secretariat and Documentation Department Instructor, T.R. Ayvansaray University, İstanbul. kadriyesonmez@ayvansaray.edu.tr, https://orcid.org/0000-0001-5293-7303

3 Department of Health Management, T.R. Istanbul Arel University, Istanbul. suatpeker@arel.edu.tr, https://orcid.org/0000-0001-8451-8234

4 Department of Health Management, T.R. Istanbul Arel University, Istanbul.ibrahimhalilcankul@arel.edu.tr, https://orcid.org/0000-0002$4521-4470$ 


\section{INTRODUCTION}

The health sector is a sector where services for human life are offered uninterrupted under all conditions. The concept of leadership is of great importance among the factors that directly affect employees' individual productivity. The concept of leadership is among the most emphasized topics by researchers from past to present. According to Göksel and others, although management and administratorship have teachable aspects, leadership is an innate feature (Göksel, Aydıntan, 2012:247-71; Koç, Topaloğlu, 2012; Koçel, 2015:36; Tengilimoğlu, 2005:1-16). There are many theoretical and empirical studies that try to explain the concepts of leader and leadership with different theories and approaches (Tengilimoğlu, 2005). As a result of these researches, it has been understood that leaders give direction with clear instructions and manage interpersonal relations well, and leadership training has begun to be organized in these dimensions. Nowadays, it is not possible to talk about a leadership model that will appeal to every group, anytime and in all situations. Developments in the field of organizational behavior and managementorganization and the emerging new concepts have led to the emergence of new leadership types.

The leadership understanding emerging from the cultural differences of Eastern societies has been named as paternalistic leadership (Çalıskan, Özkoc, 2016:240-255). It has been determined by research that the leadership understanding of Eastern cultures and the leadership understanding of Western cultures differ. In Turkey Aycan and Kanungo (2000) in a research conducted by, it is understood that employees expect paternalistic behavior from their manager or leader. The concept of paternalism derives from patriarchy (Pellegrini, Scandura, 2006: 37; Suche et al.2011). Paternalistic leadership understanding that takes place in Eastern societies; it has been defined that authority is integrated with care and respect and the leader protects his subordinate like a father as a process in which it expects loyalty and obedience in return (Yeşilkayalı, Kılıç, 2012; Blackburn, 1996: 645; Öcal, Gümüştekin, 2012: 276-
281; Karahan, 2008: 145-62; Uysal, et al., 2012: $25-$ 57). Also Westwood and Chan define paternalistic leadership as the integration of authority with care and respect. Leaders' behaviors on the grounds of being useful lead to the limitation and damage of their subordinates' personal autonomy from time to time. For this reason, it has been concluded that paternalism cannot be seen as an example of professionally appropriate behavior today (Efeoğlu, İplik, 2011: 343-360; Gün, 2016: 253-266).

Cynicism is the life philosophy of individuals whose goals are to achieve individual freedom and become self-sufficient and who reject the basic rules of courtesy, morals and customs and who think nothingnatural is shameful. People who act according to this philosophy are named with the word "cynic" (Fındık, Eryeşil, 2012). Organizational cynicism is a concept that the behavior pattern that develops due to the negative feelings of the employee towards the corporate culture and rules and include the cognitive dimension of these behaviors. According to Akman and Musaoğlu, it is the assumption that factors such as trust and sincerity are used as utilitarian by the leaders who do fraudulent works (Akman, 2013; Özer Musaoğlu, 2017). The thought of cynicism reveals bad thoughts that include reactive feelings. The cynical feelings raised against the organization, which is believed to cause suspicion and disappointment, lead the employee to be discontent. It puts the emotionality of the individual in the foreground and keeps him away from the work environment (Çivilidağ, 2015:6; Kalağan,2009). It is possible to talk about personal and organizational factors that make up organizational cynicism and have direct or indirect effects on its occurrence. Organizational cynicism can be a negative attitude arising from negative personal feelings such as laziness and negative personality, or it can be interpreted as negative attitudes triggered by organizational attitudes such as wrong organizational policies, organizational injustice and inequality (Yildız, 2013: 853-859; Findik, 2012).

\section{MATERIAL AND METHOD}

Ethics Committee approval for the study was received from Beykent University. In this section, the materials and methods of the research about the effect of paternalistic leadership on organizational cynicism are given and the findings obtained are interpreted.

\subsection{Purpose and Importance}

The aim of the study is to investigate the effect of paternalistic leadership on the cynical attitudes of employees in the health sector and to the determination of the dimensions in which it occurs.
Three hypotheses designed for the subject were tested and their validity was evaluated. These hypotheses are given below:

H1 Paternalistic leadership behaviors of managers have an effect on employees' perception of organizational cynicism.

$\mathrm{H} 2$ In public hospitals, there is a significant relationship between the paternalistic leadership behaviors of managers and the organizational cynicism perception of the employees. 
H3 There is a significant relationship between the paternalistic leadership behaviors of managers and the organizational cynicism perception of the private sector healthcare workers.

\section{2. Population and Sampling}

The universe of the research consists of approximately 8,000 employees of 30 (22 private and 8 public) inpatient healthcare institutions in IstanbulFatih Health Service Region. The sample number was determined as $n=370$ in the calculation made in order to test the findings of the study with $95 \%$ reliability (Yazıcıoğlu and Erdoğan, 2004:50; www.etikarastirma.com). "Simple Random Sampling" method was used in the selection of the participants in the study. In order to keep the sample size high, 1280 questionnaire forms were distributed, 771 forms that were properly filled out of the 859 returned forms were evaluated, 88 of them were not included in the evaluation because they were deemed incorrect.

\subsection{Data collection tool}

Three different measurement tools (scales) were used as data collection tools. The scale developed by Cheng, Chou, Wu, Huang and Farh in 2004 was used to measure paternalistic leadership. A total of 25 questions were asked to measure the three dimensions of paternalistic leadership: benevolence, authoritarianism, and morality.

To measure organizational cynicism, the "Organizational Cynicism Scale" developed by Brandes, Dharwadkar and Dean in 1999 was used. The scale includes a total of 14 statements (questions) that measure the three dimensions of organizational cynicism: cognitive, affective and behavioral. There are 6 questions to evaluate the demographic characteristics of the participants in the last part of the questionnaire. 6 and 5 Likert question types were used in the scales.

\subsection{Analysis Method}

The density of the demographic information of the participants was examined by frequency and percentage distribution. Cronbach's Alpha coefficients were calculated for the validity and reliability of the questionnaire. Correlation Test was used for the relationship between dependent and independent variables in testing the accuracy of the hypotheses established for the research. The Independent Sample $t$ test was used for the public and private sector comparisons of the obtained results.

\section{RESULTS}

As a result of the analysis of the data obtained from the scales, the following findings were obtained.

Table 1. Reliability Tests of Scales for Paternalistic Leadership, Organizational Culture and Organizational Cynicism

\begin{tabular}{|c|c|c|}
\hline \multicolumn{3}{|c|}{ Cronbach's Alpha Value } \\
\hline $\begin{array}{l}\text { Paternalistic } \\
\text { Leadership Scale } \\
(\mathrm{N}=25)\end{array}$ & $\begin{array}{c}\text { Organizational } \\
\text { Cynicism Scale } \\
(\mathrm{N}=14)\end{array}$ & $\begin{array}{c}\text { Both } \\
\text { Scales } \\
(\mathrm{N}=64)\end{array}$ \\
\hline \multicolumn{1}{|c|}{0,950} & 0,870 & 0,902 \\
\hline
\end{tabular}

The reliability of the scale is interpreted as follows, depending on the alpha coefficient. If 0.00 $<\alpha<0.40$, the scale is not reliable, if $0.40<\alpha<0.60$ the reliability of the scale is low, if $0.60<\alpha<0.80$ the scale is quite reliable, $0.80<\alpha<1$, If 00 , the scale is highly reliable. Based on the results in the table, it was concluded that the scales used were highly reliable.
Table 2. Demographic Characteristics of the Participants

\begin{tabular}{|c|c|c|c|c|}
\hline \multirow{2}{*}{$\begin{array}{l}\text { Demographic } \\
\text { Variables }\end{array}$} & \multicolumn{2}{|c|}{ Public } & \multicolumn{2}{|c|}{ Private } \\
\hline & $\mathbf{n}$ & $(\%)$ & $\mathbf{n}$ & $(\%)$ \\
\hline \multicolumn{5}{|l|}{ Gender } \\
\hline Female & 288 & 64,1 & 218 & 67,7 \\
\hline Male & 161 & 35,9 & 104 & 32,3 \\
\hline Total & 449 & 100,0 & 322 & 100,0 \\
\hline \multicolumn{5}{|l|}{ Age } \\
\hline $18-24$ & 54 & 12,0 & 115 & 35,7 \\
\hline $25-34$ & 173 & 35,8 & 121 & 37,6 \\
\hline $35-44$ & 152 & 33,9 & 75 & 23,3 \\
\hline $45-50$ & 43 & 9,6 & 8 & 2,5 \\
\hline $51+$ & 27 & 6,0 & 3 & 0,9 \\
\hline Total & 449 & 100,0 & 322 & 100,0 \\
\hline \multicolumn{5}{|c|}{ Education level } \\
\hline $\begin{array}{l}\text { Primary } \\
\text { education }\end{array}$ & 31 & 6,9 & 11 & 3,4 \\
\hline $\begin{array}{l}\text { High school } \\
\text { graduate }\end{array}$ & 113 & 25,2 & 126 & 39,1 \\
\hline $\begin{array}{l}\text { Associate } \\
\text { Degree- } \\
\text { Undergraduate }\end{array}$ & 217 & 48,3 & 151 & 46,9 \\
\hline $\begin{array}{l}\text { Master and } \\
\text { above }\end{array}$ & 55 & 12,3 & 14 & 4,3 \\
\hline $\begin{array}{l}\mathrm{PhD} / \\
\text { Specialist }\end{array}$ & 33 & 7,3 & 20 & 6,2 \\
\hline Total & 449 & 100,0 & 322 & 100,0 \\
\hline
\end{tabular}


Table 2. Demographic Characteristics of the Participants (continuation of the table)

\begin{tabular}{|l|r|r|r|r|}
\hline Jobs & \multicolumn{5}{|c|}{$\mid$} \\
\hline Manager & 16 & 3,6 & 27 & 8,4 \\
\hline Physician & 36 & 8,0 & 20 & 6,2 \\
\hline Pharmacist & 11 & 2,4 & 10 & 3,1 \\
\hline Nurse & 194 & 43,2 & 104 & 32,3 \\
\hline Technician & 27 & 6,0 & 22 & 6,8 \\
\hline $\begin{array}{l}\text { Medical } \\
\text { secretary }\end{array}$ & 41 & 9,1 & 57 & 17,7 \\
\hline Servant & 57 & 12,7 & 19 & 5,9 \\
\hline Other & 67 & 14,9 & 63 & 19,6 \\
\hline Total & $\mathbf{4 4 9}$ & $\mathbf{1 0 0 , 0}$ & $\mathbf{3 2 2}$ & $\mathbf{1 0 0 , 0}$ \\
\hline Seniority & & & & \\
\hline $\begin{array}{l}\text { Less than 1 } \\
\text { year }\end{array}$ & 40 & 8,9 & 79 & 24,5 \\
\hline 1-5 years & 148 & 33,0 & 161 & 50,0 \\
\hline 6-10 years & 129 & 28,7 & 43 & 13,4 \\
\hline 11-15 years & 58 & 12,9 & 29 & 9,0 \\
\hline 16-20 years & 37 & 8,2 & 9 & 2,8 \\
\hline 21+ & 37 & 8,2 & 1 & 0,3 \\
\hline Total & $\mathbf{4 4 9}$ & $\mathbf{1 0 0 , 0}$ & $\mathbf{3 2 2}$ & $\mathbf{1 0 0 , 0}$ \\
\hline
\end{tabular}

Of the 449 public health workers participating in the study, $64.1 \%$ are women and $35.9 \%$ are men. Most of the participants are young people. The education level of its employees is very high. Although the number of private hospital employees with 16 years or more of work experience is quite low, the total rate of the number of employees with 16 years and more in public hospitals is quite high.

Table 3. Rate of Public and Private Sector Variable in Organizational Cynicism Perception Experienced in Institutions (Group Statistics)

\begin{tabular}{|l|l|l|r|l|}
\hline Organizational & Sector & $\mathrm{N}$ & Mean & Std. deviation \\
\cline { 2 - 5 } $\begin{array}{l}\text { Cynicism } \\
\text { Perception }\end{array}$ & Private & 322 & 2,8409 & 0,76363 \\
\cline { 2 - 5 } & Public & 449 & 2,8914 & 0,73141 \\
\hline
\end{tabular}

Table 4. Ratio of Public and Private Sector Variable in Organizational Cynicism Perception Experienced in Institutions Independent Sample T Test

\begin{tabular}{|c|c|c|c|c|c|c|}
\hline \multicolumn{2}{|c|}{} & \multicolumn{2}{|c|}{$\begin{array}{c}\text { Equality of } \\
\text { Variance Test }\end{array}$} & \multicolumn{3}{c|}{ T-Test } \\
\cline { 3 - 7 } & $\mathrm{F}$ & $\mathrm{p}$ & $\mathrm{t}$ & $\begin{array}{c}\text { Std. } \\
\text { deviation }\end{array}$ & Sig. (2-tailed) \\
\hline $\begin{array}{c}\text { Organizational } \\
\text { Cynicism } \\
\text { Perception }\end{array}$ & $\begin{array}{c}\text { Equivalent } \\
\text { variances }\end{array}$ & 1,524 & $0,217^{*}$ & $-0,928$ & 769 & 0,354 \\
\cline { 2 - 7 } & $\begin{array}{c}\text { Variances that are } \\
\text { not equal to }\end{array}$ & & & $-0,921$ & 673,453 & 0,357 \\
\hline
\end{tabular}

$* \mathrm{p}<0,05$

According to the healthcare professionals working in public and private health institutions, the rates of organizational cynicism perception are not significantly different between the groups in the independent sample $\mathrm{t}$ test analysis $(\mathrm{t}=0.928$; $\mathrm{p}$ >
0.05). In other words, no significant difference was found between the perception of organizational cynicism experienced in public hospitals and the perception of organizational cynicism experienced in private hospitals.

Table 5. The Correlation Test for the Relationship Between Managers 'Paternalistic Leadership Behaviors and Employees' Perception of Organizational Cynicism

\begin{tabular}{|c|c|c|c|}
\hline \multicolumn{2}{|c|}{} & Paternalistic Leadership & $\begin{array}{c}\text { Organizational } \\
\text { Cynicism }\end{array}$ \\
\hline \multirow{2}{*}{$\begin{array}{c}\text { Paternalistic } \\
\text { Leadership }\end{array}$} & Pearson Correlation & & 0,025 \\
\cline { 2 - 4 } & Sig. (2-tailed) & & $0,497^{*}$ \\
\hline \multirow{2}{*}{$\begin{array}{c}\text { Organizational } \\
\text { Cynicism }\end{array}$} & N & & 771 \\
\cline { 2 - 4 } & Sig. (2-tailed) & 0,025 & \\
\cline { 2 - 4 } & $\mathrm{N}$ & 771 & \\
\hline
\end{tabular}

$* \mathrm{p}<0,05$ 
In Table 5, whether there is a relationship between the paternalist leadership behaviors of managers and the organizational cynicism perception of healthcare professionals was analyzed by correlation analysis. As a result of the correlation test regarding the relationship between leadership behaviors and employees' perception of organizational cynicism, it was concluded that there was no significant relationship between variables $(\mathrm{p}=$ $0.497)$.

Table 6. Correlation Test on the Relationship Between Paternalist Leadership Behaviors of Public Hospitals Managers and Employees' Perception of Organizational Cynicism

\begin{tabular}{|c|c|c|c|}
\hline \multicolumn{2}{|c|}{} & Paternalistic Leadership & Organizational Cynicism \\
\hline \multirow{2}{*}{$\begin{array}{c}\text { Paternalistic } \\
\text { Leadership }\end{array}$} & Pearson Correlation & & 0,028 \\
\cline { 2 - 4 } & Sig. (2-tailed) & & $0,560^{*}$ \\
\cline { 2 - 4 } & $\mathrm{N}$ & 449 \\
\hline \multirow{2}{*}{$\begin{array}{c}\text { Organizational } \\
\text { Cynicism }\end{array}$} & Pearson Correlation & 0,028 & \\
\cline { 2 - 4 } & Sig. (2-tailed) & $0,560^{*}$ & \\
\cline { 2 - 4 }$* 0<05$ & $\mathrm{~N}$ & 449 & \\
\hline
\end{tabular}

In the Correlation Test (Table 6), which was conducted to measure the relationship between paternalist leadership behaviors of managers and employees' perception of organizational cynicism in public hospitals, the result was $\mathrm{p}=0.560$. Accordingly, it was concluded that there was no relationship between paternalistic leadership behaviors and employees' perception of organizational cynicism. Since there is no significant relationship between the two variables, it cannot be mentioned that paternalist leadership has an effect on organizational cynicism.

Table 7. Correlation Test for the Relationship Between Paternalistic Leadership Behaviors of Managers in Private Hospitals and Employees' Perception of Organizational Cynicism

\begin{tabular}{|c|c|c|c|}
\hline \multirow{2}{*}{} & Paternalistic Leadership & Organizational Cynicism \\
\hline \multirow{3}{*}{$\begin{array}{c}\text { Paternalistic } \\
\text { Leadership }\end{array}$} & Pearson Correlation & & 0,025 \\
\cline { 2 - 4 } & Sig. (2-tailed) & & $0,648^{*}$ \\
\cline { 2 - 4 } & $\mathrm{N}$ & & 322 \\
\hline \multirow{2}{*}{$\begin{array}{c}\text { Organizational } \\
\text { Cynicism }\end{array}$} & Pearson Correlation & 0,025 & \\
\cline { 2 - 4 } & Sig. (2-tailed) & $0,648^{*}$ & \\
\cline { 2 - 4 } & $\mathrm{N}$ & 322 & \\
\hline
\end{tabular}

$* \mathrm{p}<0,05$

In the Correlation Test (Table 7), which was conducted to measure the relationship between paternalistic leadership behaviors of managers in private hospitals and employees' perception of organizational cynicism, the result was $\mathrm{p}=0.648$. Since $\mathrm{p}>0.05$, it is concluded that there is no relationship between paternalist leadership behaviors and employees' perception of organizational cynicism in private hospitals. Since there is no significant relationship between the two variables, it is not possible to talk about the effect of paternalist leadership on organizational cynicism.

\section{DISCUSSION AND CONCLUSION}

It was determined by this study that paternalistic leadership behaviors of public and private sector hospital managers do not have an effect on employees' perception of organizational cynicism. When the correlation test results for the relationship between paternalist leadership and organizational cynicism were analyzed as a result of the analysis of the data obtained from the questionnaires applied to public and private sector hospital employees, it was seen that there was no significant relationship between two variables. Since there is no significant relationship between the two variables, it has been concluded that the effect of paternalistic leadership on organizational cynicism cannot be mentioned. Employees who are in a paternalistic relationship with the manager or leader see the hospital environment as a family environment, obey their leaders, accept the leader's authority by helping their leaders in non-business matters, and believe that the leader knows what is best for them (Çalıskan, Özkoc,2016:240-250). Although many studies on the dimensions, effects and importance of leadership in the health sector have been examined in the literature reviews on the effects of leadership and its dimensions on healthcare professionals, not many 
studies have been found on the effects of the "paternalistic leadership".

The study, which is concluded that leadership positively affects employees' positive feelings and dependency towards the organization and examines the relationship between leadership and organizational commitment, was conducted in hospitals in Afyonkarahisar (Karahan, 2008:145-62). In a study conducted by Yeşilkayalı and Kılıç in 2012, the determination of the managers as weak managers in the hospital where the study was applied was evaluated as an indicator of the regression of leadership practices in the public (Yeşilkayalı, Kılıç, 2012). As a result of a study conducted by Göksel and Aydintan, which examined the leadership characteristics of nurses, it was concluded that leadermember interaction positively affected organizational commitment (Göksel A., Aydıntan B.,2012). In a study conducted in the city center of Isparta; by determining hospital staff are associated with their managers from which participatory, charismatic, autocratic, democratic, liberal, paternalist, transformational and operational types of leadership, and the effects of employees' leadership perceptions on work productivity levels were examined (Uysal et al., 2012).

In another study, it has been determined that public and private sector organization leaders show statistically significant differences in some behavioral variables. These differences are the variables that include creating a friendly environment away from conflict, displaying a friendly attitude and behavior (Tengilimoğlu 2005:1-16). In a study conducted in various hospitals in Ankara, the leadership orientations of the nurses in charge of the service were examined by taking into account various variables and various suggestions were presented for manager nurses to develop their leadership towards people within the scope of the applied scale (Erkan, Aban S, 2006).

Employees with a high motivation for organizational commitment are problem solvers instead of producing problems (Erdem, 2007:64; Karahan, 2008:145-162). It seeks to increase the level of organizational commitment of both public and private sector employees (Göksel, Aydıntan, 2012:247). Because employees with high organizational commitment make extra effort in fulfilling their duties and achieving organizational goals. Employees want to perform their professional activities in a healthy way in their business life and work in a peaceful environment with a sense of confidence. The primary factors that are effective in providing and maintaining the ideal environment and protecting the individual from harmful environmental factors should be taken into consideration by the management (Kılıçarslan, Kaya, 2016:9-25; Yalçınkaya,2014:106-130). Managers should be aware of the importance of meeting both physical and psychological needs of employees in order to prevent the decrease in organizational commitment by developing negative emotions such as feelings of burnout, cynicism, and intention to quit. The fact that an employee who has a high sense of trust in his manager or leader shows his manager's paternalist behavior as an excuse for the cynical attitudes that he develops against the institution and its rules. For future research, it is recommended to examine the effects of paternalist leadership on organizational trust, organizational belonging, organizational happiness or job satisfaction in healthcare institutions.

\section{REFERENCES}

Akman, G. (2013), "Hastane ve Sağlık Kuruluşlarında Sağlık Calıșanlarının Örgütsel ve Genel Sinizm Düzeylerinin Karşılaştırılması”, İstanbul Üniversitesi, Sosyal Bilimler Enstitüsü, Yayınlanmış Yüksek Lisans Tezi, İstanbul.

Aycan, Z. ve Kanungo, R. N. (2000) "Toplumsal Kültürün Kurumsal Kültür ve İnsan Kaynakları Uygulamaları Üzerine Etkileri”, Türk Psikologlar Derneği Yayınları, Ankara, s. 25-47.

Blackburn, S., (1996), The Oxford Dictionary of Philosophy, Oxford University Press.

Cheng, B. S., Chou, L. F., Wu, T. Y., Huang, M. P., \& Farh, J. L. (2004); Paternalistic Leadership and Sub-Ordinates Responses: Establishing A Leadership Model In Chinese Organizations, Asian Journal of Social Psychology, 7: 89-117.

Çalıskan, N., Özkoc, A., G., (2016), “Örgütlerde Paternalist Liderlik Algısına Etki Eden Ulusal Kültür Boyutlarının Belirlenmesi”, Journal of Yasar University, 11 (44):240-250.

Çivilidağ, A.,(2015), “Öğretim Elemanlarında Örgütsel Sinizm ve İşe Yabancılaşma Arasındaki İlişkide Yaşam Doyumunun Aracı Rolü” İş Güç, Endüstri İlişkileri ve İnsan Kaynakları Dergisi, 17: 4.
Dean, James W., Brandes P. and Dharwadkar, R. (1999), "Organizational Cynicism", Academy of Management Review, 23: 2, 341-52.

Efeoğlu, İ.E., İplik, E., (2011), “Algılanan Örgütsel Adaletin Örgütsel Sinizm Üzerindeki Etkilerini Belirlemeye Yönelik İlaç Sektöründe Bir Uygulama", Çukurova Üniversitesi Sosyal Bilimler Enstitüsü Dergisi, 20 (3):343-360.

Erkan E., Aban S., (2006), "Devlete ve Özel Sektöre Bağl Hastanelerde Çalışan Servis Sorumlu Hemşirelerinin İşe ve İnsana Yönelik Liderlik Yönelimlerinin İncelenmesi”, Hemşirelik Yüksekokulu Dergisi 1:13.

Erdem R., (2007), “Örgüt Kültürü Tipleri İle Örgütsel Bağlılık Arasındaki İlişki: Elazığ İl Merkezindeki Hastaneler Üzerinde Bir Çalışma”, Eskişehir Osmangazi Üniversitesi İktisadi ve İdari Bilimler Fakültesi Dergisi, s. 64.

Fındık, M., Eryeşil, K., (2012), "Örgütsel Sinizmin Örgütsel Bağlılık Üzerindeki Etkisini Belirlemeye Yönelik Bir Araştırma”, International Iron \& Steel Symposium, Karabük, Türkiye

Göksel A., Aydıntan B., (2012), "Lider-Üye Etkileşimi Düzeyinin Örgütsel Bağlılık Üzerine Etkisi: Görgül Bir Araştırma”, Süleyman 
Demirel Üniversitesi İktisadi ve İdari Bilimler Fakültesi Dergisi, $17: 47-71$.

Gün, G., (2016), “Örgütsel Sinizm İle İş Tatmin Algıları Arasındaki İlişkinin İncelenmesi: Turizm Sektöründe Bir Araştırma", The Journal of Academic Social Science 4 (37):253266.

Kalağan, G.,(2009) “Araştırma Görevlilerinin Örgütsel Destek Algıları İle Örgütsel Sinizm Tutumları Arasındaki Ïlişki” Yüksek Lisans Tezi, Akdeniz Üniversitesi Sosyal Bilimler Enstitüsü, Antalya.

Karahan A. (2008), "Hastanelerde Liderlik ve Örgütsel Bağlllık Arasındaki İlişkinin İncelenmesi", Sosyal Bilimler Dergisi, Sayı:10:145-62.

Kilıçarslan, S., Kaya, A., (2016), "Mobbingin Örgütsel Sinizm Üzerine Etkisi Hemşireler Üzerinde Bir Uygulama” Süleyman Demirel Üniversitesi Sosyal Bilimler Enstitüsü Dergisi 3 (25):925.

Koç, H., Topaloğlu, M.,(2012), İşletmeciler İçin Yönetim Bilimi, Seçkin Yayınları, 2. Baskı, Ankara,

Koçel, T., (2015), İşletme Yöneticiliği, Beta Yayıncılık,16. Baskı, İstanbul.

Öcal,H., Gümüștekin, G. E., Çağ, A., (2012), "Yöneticilerin Otantik Liderlik Düzeylerinin Örgütsel Sinizm Üzerindeki Etkisi ve Bir Araştırma", 20. Ulusal Yönetim ve Organizasyon Kongresi Bildiriler Kitab1, s. 276-281.

Suche, S.J., Badaracco, J.L., Bell, D., Goldberg L., Henderson, R., Kaplan, R., Pozen, R., Reiling, H.B., Rose, C., Sandra J.( 2011), "Leadership And Corporate Accountability" Harvard Business School, USA.
Pellegrini, E.K. and Scandura, T.A. (2006), "Leader-Member Exchange (LMX), Paternalism, and Delegation In The Turkish Business Culture: An Empirical Investigation", Journal of International Business Studies, s. 37, 264-79.

Tengilimoğlu D. (2005). "Kamu ve Özel Sektör Örgütlerinde Liderlik Davranıșı Özelliklerinin Belirlenmesine Yönelik Bir Alan Çalışması" Elektronik Sosyal Bilimler Dergisi, ISSN:1304-0278, Güz, 4:1-16.

Uysal, S. A., Keklik B., Erdem, R., Celik, R., (2012) "Hastane Yöneticilerinin Liderlik Özellikleri ile Çalışanların İş Üretkenlik Düzeyleri Arasındaki İlişkilerin İncelenmesi” Hacettepe Sağlık İdaresi Dergisi, C. 15, 1:25-57.

Özer Musaoğlu, B. N. (erişim t. 23/05/2017) “Günlük Hayatımızın Gizli Parçası: Sinizm”, http://www.academia.edu/15045991/ Sinizm.

Yalçınkaya, A. (2014), “Türkiye'de Örgütsel Sinizm: 2007-2012 Yılları Arasındaki Çalışmalar Üzerine Bir Değerlendirme”, İs Güc Endüstri İlişkileri ve İnsan Kaynakları Dergisi, 16/3, s.106-130.

Yazıcıoğlu, Y., Erdoğan, S., (2004), SPSS Uygulamalı Bilimsel Araştırma Yöntemleri, Detay Yayıncılık, Ankara, s.50.

Yeşilkayalı F., Kılıç B.,( 2012), "İzmir İli Kamu Sağlığı Yöneticilerinin Liderlik Davranışları”, 15. Ulusal Halk Sağlığı Kongresi, Bursa,

Yıldız, K., (2013), "Örgütsel Bağll1ık İle Örgütsel Sinizm ve Örgütsel Muhalefet Arasındaki İlișki”, Turkish Studies International Periodical For The Languages, Literature and History of Turkish or Turkic Volume 8/6 Spring, Ankara, s. 853-879,

http://etikarastirma.com/tr/icerik/bilgi-merkezi/10, (erişim tarihi. 20.05.2019) 